\title{
Az ón(II)-halogenidek koordinációs kémiájának jelentősége a platinakatalizált hidroformilezési reakcióban
}

\author{
PAPP Tamara ${ }^{\mathrm{a}}$ KOLLÁR László ${ }^{\mathrm{a}, \mathrm{b}}$ és KÉGL Tamás ${ }^{\mathrm{a}, \mathrm{b},{ }^{*}}$ \\ ${ }^{a}$ Pécsi Tudományegyetem, Kémiai Intézet, Szervetlen Kémia Tanszék, Ifjúság útja 6., 7626, Pécs \\ ${ }^{b}$ Pécsi Tudományegyetem, MTA-PTE Szelektiv Kémiai Szintézisek Kutatócsoport, Ifjúság útja 6., 7626, Pécs
}

\section{Bevezetés}

A hidroformilezést, vagy másik, kevésbé elterjedt nevén, oxo reakciót Otto Roelen fedezte fel 1938-ban. ${ }^{1}$ A reakció lényegét tekintve szénmonoxid és hidrogén olefinekre történő addíciója, mely valamilyen átmenetifém katalizátor segítségével megy végbe. $\mathrm{A} \mathrm{C}=\mathrm{C}$ kötés funkcionalizálására épülő eljárások közül az egyik legsokoldalúbb, és leghatékonyabb szintetikus módszernek tekinthető. A reakció hőszínezetét tekintve exoterm, és termékként aldehid izomerek keletkeznek (1. Ábra). Ha a kettős kötést formázó $\mathrm{sp}^{2}$ szénatomok egyenértéküek, úgy csak egy aldehid képződik (a). Egyszeresen szubsztituált prokirális olefinekből kiindulva a lineáris aldehidek mellett királis elágazó aldehidek jöhetnek létre, amennyiben a katalizátor is optikailag aktív ligandumot tartalmaz (b). A lehetséges keletkező izomerek száma megnő, ha a reakció alkén izomerizációval kombinálódva megy végbe (c).

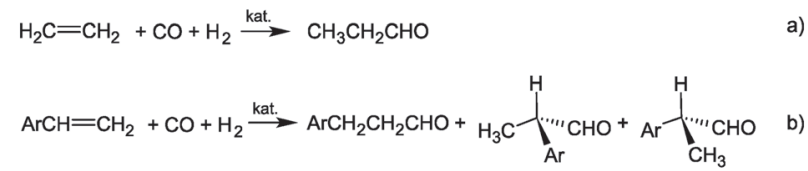

(S) (R)

$\mathrm{RCH}=\mathrm{CHCH}_{3}+\mathrm{CO}+\mathrm{H}_{2} \stackrel{\text { kat. }}{\longrightarrow}-\mathrm{RCH}_{2} \mathrm{CH}_{2} \mathrm{CH}_{2} \mathrm{CHO}+\underset{\mathrm{CHO}}{\mathrm{RCH}_{2}}{\underset{\mid}{\mathrm{CHO}}}_{\mathrm{CHCH}}^{\mathrm{CHCH}_{3}}+\underset{\mathrm{R}}{\mathrm{R}} \mathrm{HCH}_{2} \mathrm{CH}_{3}$

1. Ábra. A hidroformilezési reakció etilén (a), aromás olefinek (b) és belső olefinek (c) esetében

Katalizátorként számos átmenetifém-komplex jöhet szóba kobalt, ${ }^{2}$ ródium, ${ }^{3-6}$ platina, ${ }^{7}$ és irídium ${ }^{8}$ központi atomokkal.

A homogénkatalitikus eljárások közül a hidroformilezés a legnagyobb volumenü, évenként több mint 10 millió tonna oxo termék elöállításával. ${ }^{9}$ Ennek a legnagyobb része az aldol dimerizációval 2-etil-hexanollá alakítható butiraldehid, mely a mủanyaglágyítóként népszerü dioktil-ftalát egyik alapanyaga. $\mathrm{Az}$ aldehidek önmagában is értékes termékek lehetnek, azonban (gyakran tandem, vagy dominó reakcióban ${ }^{10}$ ) továbbalakíthatók alkoholokká, karbonsavakká, vagy aminokká. A királis aldehideket eredményező aszimmetrikus hidroformilezés az enantiomerikusan tiszta termékek iránt egyre nagyobb igénnyel fellépő gyógyszer- és növényvédőszer ipar számára válik jelentőssé.

A hidroformilezéssel kapcsolatos eredményeket az utóbbi időszakban is számos összefoglaló tanulmány dolgozta fel, ezek közül csak az alternatív fémeket, ${ }^{11}$ az iparilag jelentős alkalmazásokat, ${ }^{12}$ és a hidroformilezéssel kapcsolatos elméleti számításokat ${ }^{13}$ összegyüjtő munkákat emeljük itt ki.

A hidroformilezés általános mechanizmusát tekintve viszonylagos konszenzus alakult ki az elmúlt két évtizedben. A föbb elemi lépések megegyeznek, függetlenül attól, hogy a katalizátor kobalt, ${ }^{14}$ ródium, ${ }^{15}$ vagy platina $^{16}$ központi atomra épül (2. Ábra).

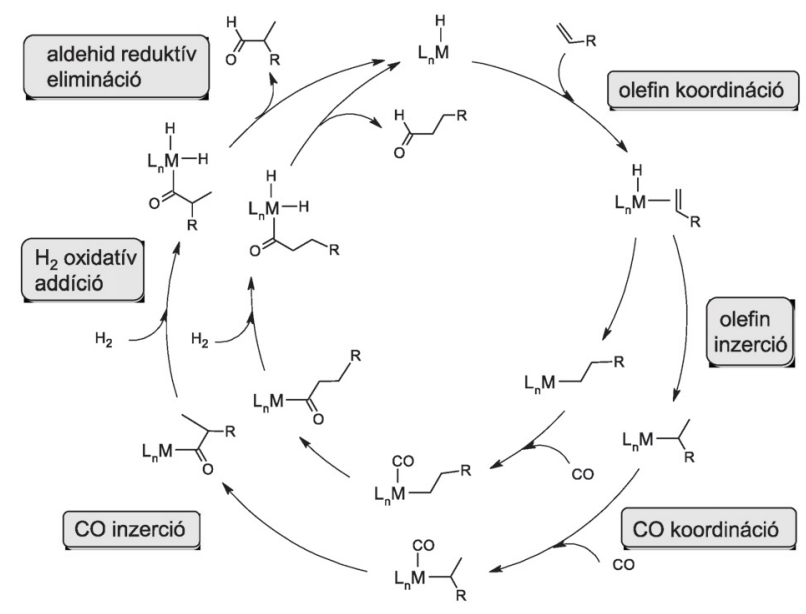

2. Ábra. A hidroformilezés általános mechanizmusa

A reakció egy átmenetifém-hidrido komplexre történő olefin koordinációval indul, majd folytatódik az alkén fém-hidrogén kötésbe történő formális beékelődésével (olefin inzerció), mely valójában inkább a hidrido ligandum valamelyik (eredetileg alkén) szénatomra történő vándorlását jelenti. Ha az olefin az etilénnél nagyobb szénatomszámú, akkor itt elágazik a reakciómechanizmus, ugyanis attól függően, hogy a hidrid melyik szénatomra kerül át, alakul ki elágazó, vagy lineáris átmenetifém-alkil komplex. Ha az alkén prokirális, akkor az elágazó alkil komplexek között már megjelenik a két optikai izomer is. A koordinatíve telítetlen komplexre általában exoterm reakcióban koordinálódik egy szénmonoxid a külső gáztérből, majd ez karbonil ligandumként beékelődik a fém-alkil szén kötésbe, ily módon koordinatíve telítetlen acil-komplex izomerek alakulnak ki. A dihidrogén molekula oxidatív addíciója ezen acil-komplexekre történik meg, majd az így létrejövő dihidrido-komplexek egyik hidrogénje átkerül az acil szénre a reduktív eliminációs lépés során. A körfolyamat végeztével megkapjuk az aldehid termékeket, és visszakapjuk a hidrido-komplex katalizátort. 
Az egyszerü, halogeno és foszfán ligandumokat tartalmazó platinakomplexek ritkán mutatnak katalitikus aktivitást a hidroformilezés során. Ón(II)-halogenidek jelenlétében azonban hatékony katalizátorok alakulhatnak ki. A szakirodalomban először Hsu és Orchin 1975-ben egy rövid, ${ }^{17}$ majd Schwager és Knifton 1976-ban ${ }^{18}$ egy hosszabb közleményben számolt be Pt/Sn-tartalmú aktív hidroformilező rendszerekröl. Jelen közlemény célja a Pt/Sn rendszerekben, az ón(II)-halogenidek elektronikus sajátságairól szóló ismeretek összefoglalása, alapvetően a számításos kémia területén született eredményekre alapozva. Az ón(II)-fluorid beékelődésével és az így kapott $\mathrm{Pt}_{-} \mathrm{SnF}_{2} \mathrm{Cl}$ komplex elektronszerkezetével kapcsolatos eredmények ugyanakkor jelen közleményben kerülnek először ismertetésre.

\section{Alkalmazott elméleti módszerek}

Valamennyi számítást a DFT (sűrüségfunkcionál elmélet) módszerrel végeztük el, a gradiens-korrigált PBEPBE ${ }^{19}$ funkcionál alkalmazásával, mely átmenetifém-komplexek számítására általában megbízható eredményt ad. Báziskészletként a platinához a tripla- $\zeta$ def2-TZVP bázist ${ }^{20}$ választottuk, míg az összes többi atomot a dupla- $\zeta$ def2-SVP ${ }^{20}$ báziskészlettel számoltuk az Sn és Pt atomokon a megfelelő pszeudopotenciállal. Vibrációs analízissel igazoltuk a kapott egyensúlyi geometriák valódi minimum (nincs imaginárius frekvencia) vagy átmeneti állapot jellegét (egy imaginárius frekvencia). A Bader-analízist az AIMAll programmal ${ }^{21}$ végeztük el. Az NBO analízishez a GENNBO $5.0^{22}$ programot alkalmaztuk. A számításokhoz a Gaussian $09^{23}$ programcsomagot használtuk.

\subsection{Bader-analízis}

A Bader-féle QTAIM (Quantum Theory of Atoms in Molecules) analízis ${ }^{24}$ a háromváltozós $\rho(\mathbf{r})$ elektronsürüségfüggvény topológiai vizsgálatán alapul. Kiindulópontja a kritikus pontok keresése, melyek a $\rho(\mathbf{r})$ függvény szélsőértékei, azaz azon pontok, ahol a gradiens, azaz $\nabla \rho(\mathbf{r})$ $=(0,0,0)$. A kötéskritikus pontban számított elektronsürüség ugyanakkor a kötések erősségére is enged következtetni, különösen, ha hasonló jellegü kötéseket hasonlítunk össze.

Két atom között, az ún. kötéskritikus ponton keresztül definiálható egy-egy útvonal (kötésútvonal), mely a maximális elektronsürüségü pontokat köti össze. A kötésútvonal megléte egyben a két atom közti kovalens kötés meglétének szükséges (de nem elégséges!) feltétele is. Az útvonalak segítségével információt nyerhetünk a kötések erősségéről és formájáról (pl. hajlítottság) is. Három, vagy több atom között a kötésútvonalak gyürübe is szerveződhetnek, ilyenkor a gyürün belül találunk egy ún. gyürükritikus pontot is, ahol az elektronsürüségnek (a gyürün belül) minimuma van. Találunk még olyan útvonalakat is, melyek az elektronsürüség gradiensét követik és egy-egy kötéskritikus pontban végződnek: ezek az ún. atomi medencéket határolják el egymástól. Ily módon egyfajta szemléletes képet kaphatunk az egyes atomok „,vonzáskörzetéről”.

\subsection{NBO analízis}

Egy adott $\mathrm{Y}$ hullámfüggvényhez rendelhető természetes orbitálok (NO) az egyelektronos redukált sürüségoperátor sajátfüggvényeiként definiálhatók (1. egyenlet):

$$
\hat{\Gamma} \varphi_{\mathrm{k}}=p_{\mathrm{k}} \varphi_{\mathrm{k}}
$$

ahol a $p_{k}$ sajátértékek az egyes $\ddot{o}_{k}$ természetes orbitálok populációinak feleltethetők meg. A természetes orbitálok teljes ortonormált függvényrendszert, azaz bázist alkotnak. Betöltöttségük a Pauli-elv figyelembe vételével (zárt héjú rendszerre) 0 és 2 között bármilyen értéket felvehet. Kiválasztásuknál szempont, hogy az elektronsürüség a lehető legkevesebb orbitál között legyen elosztva. Ezt úgy érhetjük el, ha az első kiválasztott próbaorbitált variációs módon maximalizáljuk, majd ugyanezt elvégezzük az összes többi orbitállal, szem előtt tartva, hogy mindegyik ortogonális legyen az összes többivel.

A természetes atomorbitálok (NAO) $\left\{k_{k}^{(\mathrm{A})}\right\}$ az „A” atom lokalizált egycentrumos orbitáljai molekuláris környezetben. ${ }^{25}$ Jellemzőjük, hogy mind intraatomosan, mind interatomosan ortogonálisak:

$$
\left\langle\varphi_{\mathrm{j}}^{(\mathrm{A})} \mid \varphi_{\mathrm{k}}^{(\mathrm{B})}\right\rangle=\delta_{\mathrm{j}, \mathrm{k}} \delta_{\mathrm{A}, \mathrm{B}}
$$

Az egyes NAO-k populációiból és a magtöltésből (ZA) számíthatók az egyes atomok parciális töltései:

$$
Q_{\mathrm{A}}=Z_{\mathrm{A}}-\sum_{\mathrm{k}} p_{\mathrm{k}}^{(\mathrm{A})}
$$

A természetes kötőorbitálok (NBO) természetes hibrid orbitálokból (NHO) $\left\{h_{A}\right\}$ állnak össze, melyek az NAO-khoz hasonlóan teljes ortonormált függvényrendszert alkotnak. Az NHO-k az NAO-k lineárkombinációi az adott centrumon:

$$
h_{\mathrm{A}}=\sum_{\mathrm{k}} a_{\mathrm{k}} \varphi_{\mathrm{k}}^{(\mathrm{A})}
$$

Az egycentrumos NBO-k közül az atomtörzsi orbitálok jellemzően tisztán NAO karakterüek, míg a magános párok (LP) egy-egy normált NHO-ból állnak elő. A kétcentrumos NBO-k az egymáshoz rendelt („egymás felé mutató”) NHO-k lineáris kombinációjával jönnek létre:

$$
\Omega_{\mathrm{AB}}=a_{\mathrm{A}} h_{\mathrm{A}}+a_{\mathrm{B}} h_{\mathrm{B}}
$$

Az $a_{A}$ és $a_{B}$ polarizációs koefficiensekre igaz, hogy $a_{A}{ }^{2}+a_{B}{ }^{2}$ $=1$. Az ortogonalitás megörzése miatt minden egyes kötő NBO-t ki kell egészíteni egy ellentétes fázisú lazító NBO-val:

$$
\Omega_{A B}^{*}=a_{\mathrm{B}} h_{\mathrm{A}}-a_{\mathrm{A}} h_{\mathrm{B}}
$$

A lokalizált NBO-k összessége az adott molekulára egy Lewis-jellegű határszerkezetet (,ideális Lewis-szerkezet”) jelöl ki.

Az NBO-k közötti donor-akceptor kölcsönhatások kiszámítása egyelektronos Hamilton-operátor (azaz a Fock, vagy DFT esetében a Kohn-Sham operátor) segítségével 
történik, NBO bázison. A diagonális (vagyis perturbálatlan) elemek az orbitálenergiákat adják meg:

$$
\varepsilon_{i}=\left\langle\Omega_{i} \mid \hat{F} \Omega_{j}\right\rangle, \quad \varepsilon_{j}^{*}=\left\langle\Omega_{j}^{*} \mid \hat{F} \Omega_{j}^{*}\right\rangle
$$

$\mathrm{Az}$ egyelektronos operátor mátrixreprezentációjának diagonálistól eltérő elemeiből a két orbitál közti donor-akceptor kölcsönhatás energiája számítható ki:

$$
\Delta E_{i \rightarrow j}=-2 \frac{\left\langle\Omega_{i} \mid \hat{F} \Omega_{j}^{*}\right\rangle^{2}}{\varepsilon_{j}^{*}-\varepsilon_{i}}
$$

Ha egy Lewis-típusú NBO-t a lehetséges perturbációs kölcsönhatások, és az azokkal kapcsolatba hozható töltésátvitelek segítségével kiegészítjük az összes lehetséges $\Omega_{\mathrm{j}}{ }^{*}$ nem Lewis NBO-val, akkor eljutunk a természetes lokalizált molekulaorbitálokhoz (NLMO), melyeknek pontosan kétszeres a betöltöttségük, azaz egy-egy elektronpárt reprezentálnak. Az ábrázolásuk (egy erre alkalmas program segítségével) hasznos segítséget nyújthat az egyes donor-akceptor kölcsönhatásokban résztvevő elektronpárok vizualizációjához.

\section{Eredmények}

A Pt-foszfin-ón-klorid rendszereket mind in situ $\left[\mathrm{PtCl}_{2}\left(\mathrm{P}_{2}\right)\right]$ $+\mathrm{SnCl}_{2}$, mind 'kipreparált' $\left[\mathrm{PtCl}\left(\mathrm{SnCl}_{3}\right)\left(\mathrm{P}_{2}\right)\right]\left(\right.$ ahol $\mathrm{P}_{2}$ két monofoszfánt, vagy egy difoszfánt jelöl) szokták alkalmazni. Bár a platinatartalmú katalizátorok aktivitása elmarad a ródiumtartalmú rendszerekétől, jelentőségük mégsem elhanyagolható, elsősorban az aszimmetrikus hidroformilezés területén, a jó kemoszelektivitás, azaz a hidrogénezett termékek csekély aránya, valamint számos esetben a jó enantioszelektivitás miatt.

Kokatalizátorként az ón(II)-fluorid sikeres alkalmazására is találunk példát. ${ }^{26} \mathrm{~A}\left[\mathrm{PtCl}_{2}\left(\mathrm{P}_{2}\right)\right]+\mathrm{SnF}_{2}$, rendszerek az ón-kloridos rendszerekhez képest kisebb katalitikus aktivitással, ugyanakkor lényegesen jobb termikus stabilitással jellemezhetők. A rendszer másik előnyös tulajdonsága az alacsony hőmérsékleten elérhető nagyobb optikai hozam volt.

\subsection{A katalitikusan aktív species kialakulása}

Általánosan elfogadott, hogy a Pt/Sn-katalizált hidroformilezési reakció aktív katalizátora a $\left[\mathrm{PtH}\left(\mathrm{SnCl}_{3}\right)\left(\mathrm{P}_{2}\right)\right]$ komplex, mely az analóg kloro-komplexböl alakul ki, a hidrogénnyomás hatására. A $\left[\mathrm{PtCl}\left(\mathrm{SnCl}_{3}\right)\left(\mathrm{P}_{2}\right)\right]$ prekurzor a megfelelő dikloro-komplexből állítható elő az ón-halogenidnek a Pt-Cl kötésbe történő beékelődésével. A beékelődés mechanizmusát Rocha és Almeida számolta MP2/HF elméleti szinten $^{27}$ (a geometriákat a Hartree-Fock módszerrel számították ki, majd az energiaértékeket a másodrendü Mřller-Plesset szinten pontosították) és azt találták, hogy a triklorosztannáto-komplex kialakulása igen kis aktiválási energiagáttal megy végbe. Hasonló eredményre jutott Wasserscheid munkatársaival, ${ }^{28}$ amikor a cisz$\left[\mathrm{PtCl}\left(\mathrm{SnCl}_{3}\right)\left(\mathrm{PH}_{3}\right)_{2}\right]$ képződési mechanizmusát vizsgálták DFT módszerrel, a B3LYP hibrid funkcionál alkalmazásával. Azt találták, hogy első lépésben az $\mathrm{SnCl}_{2}$ adduktot képez a
Pt-komplexszel, annak kloro ligandumján keresztül, és ennek viszonylag jelentős kötési energiája $(18,7 \mathrm{kcal} / \mathrm{mol})$ megmagyarázza, hogy a beékelődést leíró átmeneti állapot energiája miért lehet kisebb, mint a kiindulási állapoté, azaz dikloro-komplex és az ón-klorid energiájának az összegéé (3. Ábra).

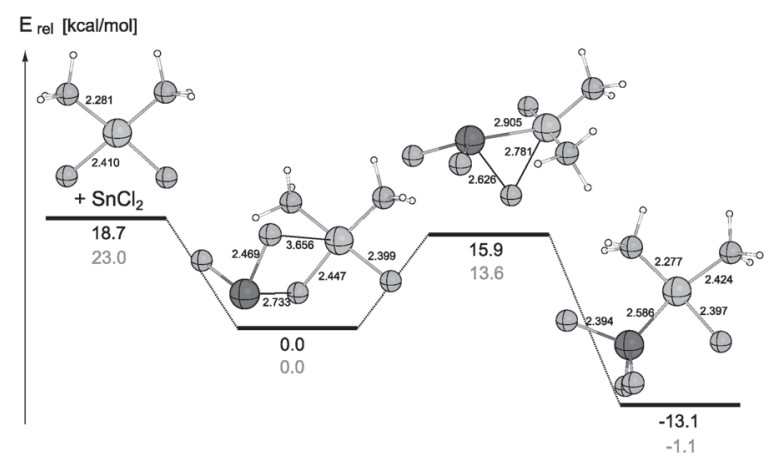

3. Ábra. Az ón(II)-halogenid Pt-Cl kötésbe történő beékelődésének mechanizmusa. A fekete színnel jelölt energiaértékek az ón-kloridra (28-es irodalom), a szürkével jelöltek az ón-fluoridra (saját eredmények) vonatkoznak. A relatív energiák az ón-halogenid addukthoz viszonyítva kerültek feltüntetésre.

$\mathrm{Az}$ ón(II)-fluorid beékelödését mi a PBEPBE sürüségfunkcionál módszer segítségével vizsgáltuk meg. Jelentős hasonlóság figyelhető meg az ón-klorid tartalmú rendszerrel, azonban a cisz- $\left[\mathrm{PtCl}_{2}\left(\mathrm{PH}_{3}\right)_{2}-\mathrm{SnF}_{2}\right]$ addukt képződése még nagyobb energianyereséggel (23,0 kcal/mol), ugyanakkor maga a beékelődés kisebb aktiválási energiával jár $(13,6 \mathrm{kcal} / \mathrm{mol})$. Lényeges eltérés viszont, hogy a cisz-[PtCl$\left.\left(\mathrm{SnF}_{2} \mathrm{Cl}\right)\left(\mathrm{PH}_{3}\right)_{2}\right]$ komplex energiája az addukthoz képest alig alacsonyabb, mindössze $1,1 \mathrm{kcal}$ a különbség. A kapott eredmény arra enged következtetni, hogy az ón-fluorid beékelődése nagyjából egyensúlyi folyamat, ami megmagyarázza, hogy az NMR-spektroszkópia segítségével miért nem találunk jól definiált $\left[\mathrm{PtCl}\left(\mathrm{SnF}_{2} \mathrm{Cl}\right)\left(\mathrm{P}_{2}\right)\right]$ komplexeket.

\subsection{Az ón-halogenidek hatása a katalitikus ciklus néhány lépése során}

A propilén $\mathrm{Pt}$-monofoszfin-ón-klorid rendszer által katalizált hidroformilezését első ízben Schwager és Knifton vizsgálta részletesebben. ${ }^{18}$ DFT számítások segítségével mi arra kerestük a választ, hogy az elterjedt B3LYP funkcionál közepes bázissal kombinálva alkalmas-e a kísérleti lineáris regioszelektivitás visszaadására. Másrészt vizsgáltuk, hogy mind az elágazó, mind a lineáris butiraldehid izomerek keletkezése milyen reakciócsatornán keresztül történik. ${ }^{29}$ Abban az esetben, ha a reakció egyik elemi lépése (vagyis itt az olefin koordináció és az azt követő beékelődés) kinetikailag kontrollált és irreverzibilis folyamat, úgy két kiválasztott regioizomer koncentráció aránya az egyes reakciócsatornák sebességi állandóiból, azok pedig az aktiválási szabadentalpiákból határozhatók meg:

$$
\frac{c 1}{c 2}=\frac{k_{1}}{k_{2}}=\frac{e^{-\frac{\Delta G_{1}^{\ddagger}}{R T}}}{e^{-\frac{\Delta G_{2}^{\ddagger}}{R T}}}=e^{-\frac{\Delta \Delta G^{*}}{R T}}
$$


$\mathrm{Az}$ oldószerhatás figyelembe vételével, katalizátorként egyszerü cisz- és transz-[PtH( $\left.\left(\mathrm{SnCl}_{3}\right)\left(\mathrm{PH}_{3}\right)_{2}\right]$ komplexeket alkalmazva a lineáris regioszelektivitásra $83 \%$ értéket kaptunk, ami igen jó egyezést mutat a 85\%-os kísérleti adattal.

Az olefininzerciós lépés kitüntetett jelentősége miatt górcső alá vettük a különféle hidrido-olefin komplexek elektronszerkezetét, hogy magyarázatot találjunk azok termodinamikai stabilitásban mutatkozó különbségeire. A komplexek alapvetően két csoportra oszthatók, aszerint, hogy a triklorosztannáto ligandum ekvatoriális, vagy axiális pozíciót foglal el. A 4. Ábrán látható, propén ligandumot tartalmazó adduktok esetében az ekvatoriális komplex egyenetlenebb elektronsürüség eloszlást eredményez a Pt-C-C síkban. Ezen három atom (vagyis a központi fém és a két olefines szénatom) között minden esetben találunk gyürükritikus pontot, és ezek az axiális adduktokban nagyjából egyenlő távolságra helyezkednek el a két Pt-C kötésútvonaltól. Az ekvatoriális komplexekben azonban a gyürükritikus pontok jóval közelebb találhatók az $\mathrm{SnCl}_{3}$ ligandumtól távolabb eső $\mathrm{Pt}-\mathrm{C}$ útvonalhoz képest. $\mathrm{Az}$ elektronsürüség torzulásával összhangban, a kötéstávolságokban is változás figyelhető meg. A Pt-Sn kötésútvonallal kisebb szöget bezáró Pt-C kötés távolsága kisebb, míg a távolabbié nagyobb lesz. A C-C kötéshossz ugyanakkor csak elhanyagolható mértékben változik.
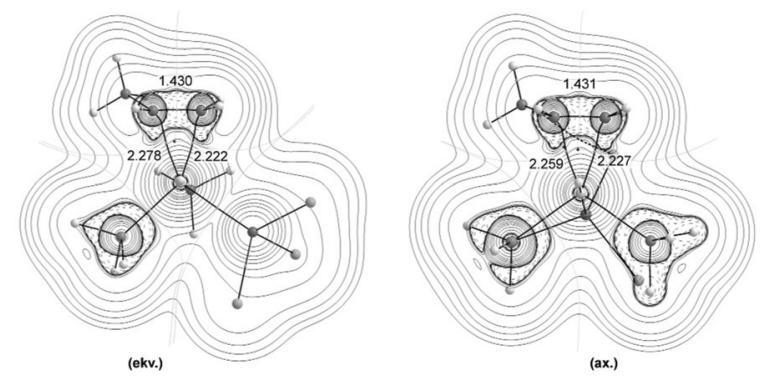

4. Ábra. A triklorosztannát ligandumot ekvatoriális (balra), illetve axiális (jobbra) pozícióban tartalmazó $\left[\mathrm{PtH}\left(\mathrm{SnCl}_{3}\right)\left(\mathrm{PH}_{3}\right)_{2}\right.$ (propén)] olefin adduktok Laplace-térképe. A kötéstávolságok Ĺ mértékegységben vannak megadva.

Az NPA töltéseket összehasonlítván az ón atom esetében nagyjából azonos értékeket kaptunk, azonban a Pt kevésbé pozitív, a hidrid hidrogének viszont kevésbé negatívak, ha az $\mathrm{SnCl}_{3}$ ligandum ekvatoriális helyzetben van. Ilyenkor nagyobb eltérés mutatkozik a kétféle foszfán ligandum (axiális és ekvatoriális) foszfor atomjának parciális töltése között; az axiális $\mathrm{P}$ atomok pozitívabbak és gyengébben koordinálódnak, mint az ekvatoriálisak.

Az olefin inzerciós lépést vizsgáltuk királis modell esetében is. A szubsztrátum sztirol volt, míg az optikailag aktív ligandum szerepét a 2,3-(difoszfano)-bután (chiraphosH) töltötte be. ${ }^{30}$ A reakciót benzol oldószerben Consiglio és munkatársai vizsgálták és elágazó regioszelektivitásra $62 \%$, míg enantioszelektivitásra $45 \%$ értékeket kaptak. ${ }^{31} \mathrm{Az}$ (R)-2-fenil-propanal keletkezett nagyobb mennyiségben. A számításaink során a PBEPBE funkcionál segítségével meghatároztuk az összes lehetséges átmeneti állapot geometriáját és relatív szabadentalpiáját, majd a regio-, valamint enantiszelektivitást a 9-es egyenlet szerint számítottuk ki. A PBEPBE geometriákon MP4(SDQ) szinten is meghatároztuk az energiákat. Különösen az ily módon korrigált értékek adtak igen jó egyezést a kísérleti enantioszelektivitásra (47\%), míg az elágazó regioszelektivitás esetében a becslés kevésbé bizonyult pontosnak $(86 \%)$. Az eltérés oka az egyszerüsített modellben keresendő, nevezetesen a királis ligandum fenil csoportjainak elhagyásában, mely a sztérikusan amúgy gátoltabb elágazó átmeneti állapotokra a valósnál kisebb energiákat eredményez. Az optikai hozamra adott kitünő becslés viszont arra enged következtetni, hogy a királis indukcióért elsősorban a ligandum váza, nem pedig a foszforokon található fenil csoportok királis elrendeződése felelős.

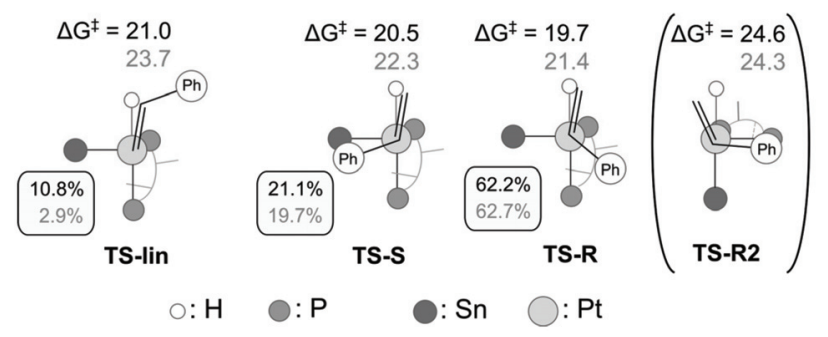

5. Ábra. A sztirol inzercióját leíró domináns átmeneti állapotok egyszerűsített szerkezete. Az aktiválási szabadentalpiák kcal/mol mértékegységben vannak megadva. Fekete színnel a PBEPBE, míg szürkével a PBEPBE geometrián az MP4(SDQ) módszerrel korrigált értékek láthatók.

Az 5. Ábrán a domináns (legalacsonyabb energiájú) átmenet állapotok láthatók, melyek egyenként a lineáris, az $(\mathrm{S})$ és az (R) reakciócsatornákat jelölik ki. Feltünő, hogy ezek mindegyikénél ekvatoriális pozícióban helyezkedik el a triklorosztannáto ligandum. Ha pl. a TS-R átmeneti állapotot összehasonlítjuk, az analóg, ám az $\mathrm{SnCl}_{3}$ ligandumot axiális helyzetben tartalmazó TS-R2 átmeneti állapottal, akkor láthatjuk, hogy utóbbi érezhetően kisebb termodinamikai stabilitással rendelkezik. Ha az elektronszerkezetben mutatott különbségeket a Bader-analízis segítségével megvizsgáljuk (6. Ábra), akkor azt tapasztaljuk, hogy a TS-R2-ben kötésútvonalat találunk a platina és mindkét olefines szénatom között, míg a TS-R esetében nem. Ez összhangban van a TS-R átmeneti állapotban megfigyelhető nagyobb Pt-C kötéstávolságokkal is. Az ekvatoriális triklorosztannát tehát nagyobb mértékben képes aktiválni a koordinált olefineket, csökkentvén így a hidridvándorlás energiagátját.

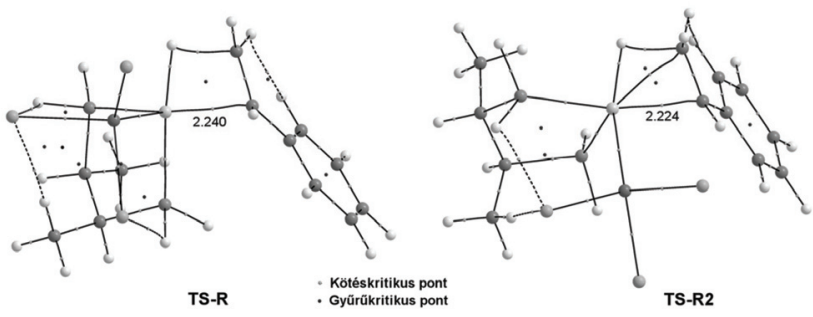

6. Ábra. A TS-R és TS-R2 átmeneti állapototokra kapott kötésútvonalak, a kötés- és gyürükritikus pontok feltüntetésével.

A hidroformilezés katalitikus ciklusának fontos lépése az oktaéderes dihidrido-komplexekből kiinduló reduktív elimináció, mely aztán az aldehid termékekhez vezet. 
Ismeretesek olyan esetek, amikor nem az olefin inzerció, hanem a végső reduktív elimináció a reakció sebességmeghatározó lépése. ${ }^{32}$ Nem meglepő, hogy a triklorosztannáto ligandum pozíciójának itt is alapvető jelentősége van az egyes komplex izomerek stabilitására és az aldehid elimináció sebességére. A monofoszfánokat tartalmazó modell esetében úgy találtuk, hogy azon dihidrido-komplexek játszanak lényeges szerepet a reakciómechanizmusban, ahol az $\mathrm{SnCl}_{3}$ ligandum az acil csoporthoz képest transz helyzetben található. A 7. Ábrán látható, a propén hidroformilezése során keletkező lineáris acil komplexek esetében például a transz komplex stabilitásban mutatkozó előnye $13,9 \mathrm{kcal} / \mathrm{mol}$ a cisz komplexhez képest. A nagyobb stabilitás feltehetőleg annak köszönhető, hogy az acil csoporthoz viszonyított transz pozíció kiegyensúlyozottabb töltéseloszlást eredményez, ahogy ez az NBO számítások alapján megállapítható.
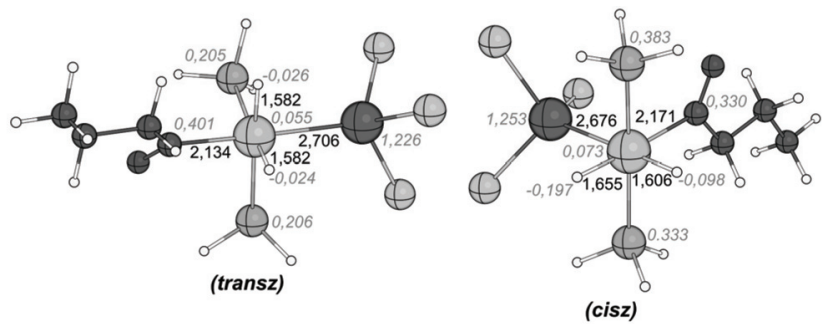

7. Ábra. Oktaéderes Pt-dihidrido-acil komplexek számított szerkezete. A kötéstávolságok Ĺ mértékegységben vannak megadva. Az NBO módszerrel számított parciális töltések dőlt betűkkel vannak jelölve.

A $\mathrm{SnCl}_{3}$ ligandum pozíciójának nagy jelentősége van a királis difoszfint tartalmazó rendszer reduktív eliminációs lépésében is. Amennyiben mind az acil csoport, mind a triklórsztannáto ligandum elhelyezkedése ekvatoriális, úgy a dihidrogén oxidatív addíciója jóval kisebb energiagáttal megy végbe, és a keletkező dihidrido-komplex is 9,0 $\mathrm{kcal} / \mathrm{mol}-\mathrm{lal}$ stabilisabb az axiális acil ligandumot tartalmazó komplexhez viszonyítva (8. Ábra).

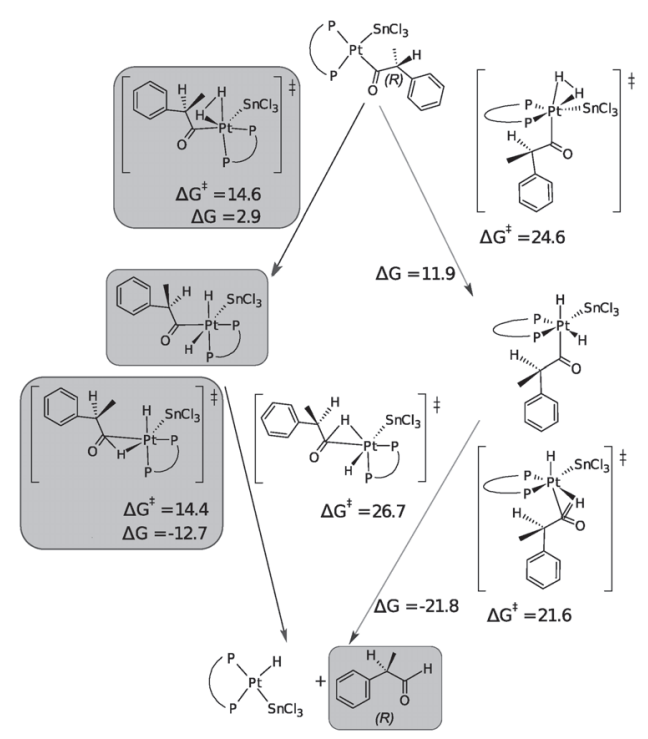

8. Ábra. Az elágazó (R)-2-fenil-propanalhoz vezető dihidrogén addíciós, majd reduktív eliminációs lépések mechanizmusa. A szabadentalpia értékek kcal/mol-ban vannak megadva.
$\mathrm{Az}$ aldehid reduktív eliminációs lépés három átmeneti állapoton keresztül mehet végbe. Az egyik lehetséges esetben az acil csoport axiális helyzetben van, és ez reagál az egyik hidriddel. A második reakcióút az ekvatoriális acil és az axiális hidrogén között zajlik le. Végül, messze a legkedvezőbb eset, amikor mindkét távozó csoport a triklorosztannáto ligandumhoz képest ekvatoriális helyzetben van.

\subsection{Az $\mathrm{SnX}_{3}$ ligandum transz-hatása: NBO számítások}

A triklorosztannát ligandum platina-foszfán kompexekben betöltött speciális szerepére már igen korán, a 60-as években felfigyeltek. Chatt és Shaw 1962-ben különböző transz-[PtHX $\left.\left(\mathrm{PEt}_{3}\right)_{2}\right]$ komplexeket karakterizált a Pt-H kötés vegyértékrezgése alapján. ${ }^{33}$ Megállapították, hogy az $\mathrm{SnCl}_{3}$ az erősebb transz-hatású ligandumok közé tartozik, mivel az $\mathrm{X}=\mathrm{Cl}$ esethez képest a karakterisztikus rezgés alacsonyabb hullámszámnál volt megfigyelhető. A Pt-H kötés eröállandójának csökkenésére szemléletes magyarázatot kaphatunk az NBO módszer segítségével. A 9. Ábrán a transz-[PtHX $\left.(\mathrm{P})_{2}\right]$ komplexekre jellemző donor-akceptor kölcsönhatást láthatjuk, mely az ón magános párja és a $\sigma_{\mathrm{Pt}-\mathrm{H}}^{*}$ lazító NBO között jön létre. A számítások egyszerüsítése végett foszfán ligandumként a $\mathrm{PH}_{3}$ szerepel, míg az $\mathrm{SnX}_{3}$ ligandumok közül a triklorosztannáton kívül vizsgáltuk az $\mathrm{SnF}_{2}$ beékelödésével keletkezö $\mathrm{SnF}_{2} \mathrm{Cl}$-t is, melynek jelentőségét a nagyobb termikus stabilitás és potenciálisan a jobb elérhető szelektivitás adja. ${ }^{26}$
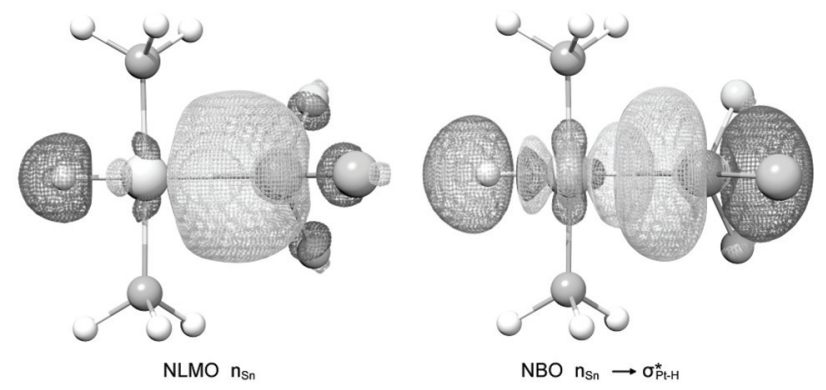

9. Ábra. A trihalogenosztannát ligandum s-donor kölcsönhatását reprezentáló elektronpár (természetes lokalizált molekula orbitál - balra), illetve a magános pár és a s ${ }_{\mathrm{Pt}-\mathrm{H}} \mathrm{NBO}-\mathrm{k}$ közötti átfedés a transz-[PtH( $\left.\left.\mathrm{SnF}_{2} \mathrm{Cl}\right)\left(\mathrm{PH}_{3}\right)_{2}\right]$ komplexben.

A transz-hatásért leginkább felelös $\mathrm{n}_{\mathrm{Sn}} \rightarrow \sigma_{\mathrm{Pt}-\mathrm{H}}^{*}$ kölcsönhatáshoz igen jelentős stabilizációs energia rendelhető hozzá (1. Táblázat, utolsó sor). $\mathrm{Az} \mathrm{SnF}_{2} \mathrm{Cl}$ ligandum esetében számított kölcsönhatási energia meghaladja az $\mathrm{SnCl}_{3}$ esetében kapott értéket, és mindkettő nagyobb, mint a kloro ligandumra kapott DE. A donor-akceptor kölcsönhatást reprezentáló elektronpárt az $\mathrm{n}_{\mathrm{Sn}}$ NBO-ból származtatható NLMO jeleníti meg, melyen markánsan látszik a domináns akceptor pálya, azaz a s ${ }^{*}{ }_{\mathrm{Pt}-\mathrm{H}}$ szerepe.

A kölcsönhatási energiákban mutatkozó különbség összhangban van a számított $\mathrm{n}(\mathrm{Pt}-\mathrm{H})$ hullámszámokkal, a Pt-H kötéstávolságokkal, valamint a természetes atomorbitál bázison számított Wiberg kötésindexekkel (WBI). A hidrido ligandum és a platina központi atom parciális töltései is 
egyértelmű tendenciát mutatnak, mivel az erősebb donor-akceptor kölcsönhatás következménye az elektronsűrüség hangsúlyosabb átvitele az X ligandumtól a Pt és a $\mathrm{H}$ atomok felé. A hidrid karakter az egyre nagyobb transz-hatással együtt így a $\mathrm{Cl}>\mathrm{SnCl}_{3}>\mathrm{SnF}_{2} \mathrm{Cl}$ sorrendben egyre erösebbé válik, ami magyarázatot adhat a katalitikusan aktív hidrido-komplexek reaktivitásban mutatkozó különbségére is.

1. Táblázat. A H-Pt kötés erősségének jellemzésére szolgáló paraméterek a transz-[PtHX $\left.\left(\mathrm{PH}_{3}\right)_{2}\right]$ komplexekben.

\begin{tabular}{llll} 
& $\mathrm{X}=\mathrm{Cl}$ & $\mathrm{X}=\mathrm{SnCl}_{3}$ & $\mathrm{X}=\mathrm{SnF}_{2} \mathrm{Cl}$ \\
\hline $\mathrm{r}(\mathrm{Pt}-\mathrm{H})(\AA)$ & 1,590 & 1,608 & 1,614 \\
$\nu(\mathrm{Pt}-\mathrm{H})\left(\mathrm{cm}^{-1}\right)$ & 2139 & 2062 & 2035 \\
$\mathrm{q}(\mathrm{H})$ & $-0,007$ & $-0,131$ & $-0,151$ \\
$\mathrm{q}(\mathrm{Pt})$ & $-0,113$ & $-0,128$ & $-0,152$ \\
$\mathrm{WBI}$ & 0,594 & 0,482 & 0,460 \\
$\Delta \mathrm{E}_{\mathrm{n} \rightarrow \sigma^{*}}(\mathrm{kcal} / \mathrm{mol})$ & 90,2 & 673,6 & 1306,1 \\
\hline
\end{tabular}

\section{Köszönetnyilvánítás}

A szerző köszönetet mond a Bolyai János Kutatási Ösztöndíj programnak és az OTKA K113177 projektnek az anyagi támogatásért.

\section{Hivatkozások}

1. Roelen, O. (to Chemische Verwertungsgesellschaft Oberhausen m.b.H.). German Patent DE 849548, 1938/1952; U.S. Patent 2327066, 1943.

2. Hebrard, F.; Kalck, P. Chem. Rev. 2009, 109, 4272-4282. https://doi.org/10.1021/cr8002533

3. van Leeuwen, P. W. N. M., Claver, C., Eds. Rhodium Catalyzed Hydroformylation; Kluwer Academic Publishers: Dordrecht, Netherlands, 2000.

4. Whiteker, G. T.; Cobley, C. J. Top. Organomet. Chem. 2012, 42, 35-46. https://doi.org/10.1007/3418_2011_28

5. Trzeciak, A. M.; Ziółkowski, J. Coord. Chem. Rev. 1999, 190-192, 883-900. https://doi.org/10.1016/S0010-8545(99)00127-7

6. Diéguez, M.; Pámies, O.; Claver, C. Tetrahedron: Asymmetry 2004, 15, 2113-2122. https://doi.org/10.1016/j.tetasy.2004.04.039

7. van Duren, R.; van der Vlugt, J. I.; Kooijman, H.; Spek, A. L.; Vogt, D. Dalton Trans. 2007, 1053-1059. https://doi.org/10.1039/b615428j

8. Piras, I.; Jennerjahn, R.; Jackstell, R.; Spannenberg, A.; Franke, R.; Beller, M. Angew. Chem., Int. Ed. 2011, 50, 280-284. https://doi.org/10.1002/anie.201001972

9. Wiese, K.-D.; Obst, D. In Catalytic Carbonylation Reactions; Beller, M., Ed.; Springer Berlin Heidelberg: Berlin, Heidelberg, 2006; Chapter Hydroformylation, pp 1-33. https://doi.org/10.1007/3418_015

10. Eilbracht, P.; Färfacker, L.; Buss, C.; Hollmann, C.; Kitsos-Rzychon, B. E.; Kranemann, C. L.; Rische, T.; Roggenbuck, R.; Schmidt, A. Chem. Rev. 1999, 99, 3329-3366. https://doi.org/10.1021/cr970413r
11. Pospech, J.; Fleischer, I.; Franke, R.; Buchholz, S.; Beller, M. Angew. Chem., Int. Ed. 2013, 52, 2852-2872. https://doi.org/10.1002/anie.201208330

12. Franke, R.; Selent, D.; Boerner, A. Chem. Rev. 2012, 112, 5675-5732. https://doi.org/10.1021/cr3001803

13. Kégl, T. RSC Adv. 2015, 5, 4304-4327. https://doi.org/10.1039/C4RA13121E

14. Huo, C.-F.; Li, Y.-W.; Beller, M.; Jiao, H. Organometallics 2003, 22, 4665-4677. https://doi.org/10.1021/om0304863

15. Decker, S. A.; Cundari, T. R. Organometallics 2001, 20, 2827-2841. https://doi.org/10.1021/om010019q

16. da Silva, J. C. S.; Dias, R. P.; de Almeida, W. B.; Rocha, W. R. J. Comput. Chem. 2010, 31, 1986-2000. https://doi.org/10.1002/jcc. 21483

17. Hsu, C. Y.; Orchin, M. J. Am. Chem. Soc. 1975, 97, 3553-3553. https://doi.org/10.1021/ja00845a064

18. Schwager, I.; Knifton, J. J. Catal. 1976, 45, 256-267. https://doi.org/10.1016/0021-9517(76)90140-8

19. Perdew, J. P.; Burke, K.; Ernzerhof, M. Phys. Rev. Lett. 1996, 77, 3865-3868. https://doi.org/10.1103/PhysRevLett.77.3865

20. Weigend, F.; Ahlrichs, R. Phys.Chem.Chem.Phys. 2005, 7, 3297-3305. https://doi.org/10.1039/b508541a

21. Keith, T. A. AIMAll (Version 15.05.18), TK Gristmill Software, Overland Park KS, USA, (aim.tkgristmill.com), 2015.

22. Glendening, E. D.; Badenhoop, K., J; Reed, A. E.; Carpenter, J. E.; Bohmann, J. A.; Morales, C. M.; Weinhold, F. NBO 5.0, Theoretical Chemistry Institute, University of Wisconsin, Madison. 2001.

23. Frisch, M. J. et al. Gaussian 09 Revision C.01. Gaussian Inc. Wallingford CT 2009.

24. Bader, R. F. W. Atoms in Molecules - A Quantum Theory; Oxford University Press, Oxford, 1990.

25. Reed, A. E.; Curtiss, L. A.; Weinhold, F. Chem. Rev. 1988, 88, 899-926. https://doi.org/10.1021/cr00088a005

26. Kollár, L.; Kégl, T.; Bakos, J. J. Organomet. Chem. 1993, $453,155-158$. https://doi.org/10.1016/0022-328X(93)80341-8

27. Rocha, W. R.; de Almeida, W. B. Int. J. Quantum Chem. 1997, 65, 643-650. https://doi.org/10.1002/(SICI)1097-461X(1997)65:5<643::A ID-QUA30>3.0.CO;2-0

28. Illner, P.; Zahl, A.; Puchta, R.; van Eikema Hommes, N.; Wasserscheid, P.; van Eldik, R. J. Organomet. Chem. 2005, 690, 3567-3576.

https://doi.org/10.1016/j.jorganchem.2005.03.029

29. Bedekovits, A.; Kollár, L.; Kégl, T. Inorg. Chim. Acta 2010, 363, 2029-2045. https://doi.org/10.1016/j.ica.2009.12.013

30. Papp, T.; Kollár, L.; Kégl, T. Organometallics 2013, 32, 3640-3650. https://doi.org/10.1021/om4002654

31. Consiglio, G.; Morandini, F.; Scalone, M.; Pino, P. J. Organomet. Chem. 1985, 279, 193-202. https://doi.org/10.1016/0022-328X(85)87017-0

32. Lazzaroni, R.; Settambolo, R.; Alagona, G.; Ghio, C. Coord. Chem. Rev. 2010, 254, 696-706. https://doi.org/10.1016/j.ccr.2009.09.032

33. Chatt, J.; Shaw, B. L. J. Chem. Soc. 1962, 5075-5084. https://doi.org/10.1039/jr9620005075 


\section{The role of tin-halides in platinum-catalyzed hydroformylation}

The hydroformylation or oxo reaction, discovered by Otto Roelen ${ }^{1}$ is the transition metal mediated formal addition of carbon monoxide and dihydrogen to the double bond of an alkene. It is one of the most versatile methods for the functionalization of $\mathrm{C}=\mathrm{C}$ bonds and therefore can be considered as a very robust synthetic tool. Substituted alkenes afford at least two aldehyde isomers. Prochiral olefins provide a racemic mixture of chiral aldehydes when achiral catalyst is used. By utilization of chiral catalysts enantioselectivity can be achieved (Fig. 1). Asymmetric hydroformylation is of great interest for the pharmaceutical and agrochemical industry, since the demand for enantiomerically pure products is constantly increasing. For instance, the hydroformylation reaction of vinyl aromatics may give rise of intermediates toward optically active functionalized 2-arylpropanoic acids, which serve as nonsteroidal anti-inflammatory agents. A wide variety of transition metal complexes may serve as catalyst for hydroformylation, with cobalt, ${ }^{2}$ rhodium, ${ }^{3-6}$ platinum, ${ }^{7}$ and iridium ${ }^{8}$ central atoms. The platinum/tin-catalyzed hydroformylation of alkenes was first reported in the literature by Hsu and Orchin ${ }^{17}$ in 1975, and Schwager and Knifton ${ }^{18}$ in 1976. Soon, the Pt-containing catalytic systems were successfully applied for asymmetric hydroformylation employing various chiral phosphanes. Remarkable enantioselectivities were reported both for "preformed" $\mathrm{PtCl}\left(\mathrm{SnCl}_{3}\right)$ (diphosphane) catalysts and for in situ $\mathrm{PtCl}_{2}$ (diphosphane) + tin(II) chloride systems. Apart from $\mathrm{SnCl}_{2}$, tin(II)-fluoride was also successfully employed as cocatalyst. ${ }^{26}{ }^{2}$

It is generally accepted, regardless of which metal is centered in the catalyst, that the initial step of hydroformylation is the coordination of the olefin onto the hydrido complex, which is usually formed when the precursor reacts with $\mathrm{H}_{2}$ under hydroformylation conditions. The formation of the alkyl complex via migratory insertion followed by $\mathrm{CO}$ addition and insertion, then the oxidative addition of $\mathrm{H}_{2}$ onto the acyl complex and the reductive elimination resulting in the initial hydrido complex and the aldehydes as products.

The goal of this study is to give an insight into the electronic structure of platinum-tin complexes and its impact for the various elementary steps of hydroformylation, such as the formation of the active catalyst, the olefin insertion of the reductive elimination of aldehyde. For the computational studies Natural Bond Orbital (NBO) analysis ${ }^{25}$ and the quantum theory of atoms in molecules ${ }^{24}$ (QTAIM) by Bader were employed.

It is assumed for $\mathrm{Pt} / \mathrm{Sn}$ catalyzed hydroformylation, that the active catalyst is complex $\left[\mathrm{PtH}\left(\mathrm{SnCl}_{3}\right)\left(\mathrm{P}_{2}\right)\right]$ (where $\mathrm{P}_{2}$ stands for diphospane or two monophosphanes) which forms from the analogous chloro complex under hydrogen pressure. The precursor $\left[\mathrm{PtCl}\left(\mathrm{SnCl}_{3}\right)\left(\mathrm{P}_{2}\right)\right]$ is either pre-prepared or can be generated in situ from $\left[\mathrm{PtCl}\left(\mathrm{SnCl}_{3}\right)\left(\mathrm{P}_{2}\right)\right]$ and $\mathrm{SnCl}_{2}$ via the insertion of tin(II) chloride into the $\mathrm{Pt}-\mathrm{Cl}$ bond. The mechanism of $\mathrm{SnF}_{2}$ insertion into the $\mathrm{Pt}-\mathrm{Cl}$ bond in complex $\left[\mathrm{PtCl}_{2}\left(\mathrm{PH}_{3}\right)_{2}\right]$ has been investigated by means of DFT calculations employing the PBEPBE functional. The formation of the adduct was found to be a rather exothermic process with somewhat higher interaction energy found for the insertion of $\mathrm{SnCl}_{2}$ by Wasserscheid and co-workers. ${ }^{28}$ The barrier for the insertion is similar for the two tin-halides, however, the formation of complex $\left[\mathrm{PtCl}\left(\mathrm{SnF}_{2} \mathrm{Cl}\right)\left(\mathrm{PH}_{3}\right)_{2}\right]$ is almost an equilibrium process, which is not a case for the $\left[\mathrm{PtCl}_{2}\left(\mathrm{PH}_{3}\right)_{2}\right]+$ $\mathrm{SnCl}_{2} \rightarrow\left[\mathrm{PtCl}\left(\mathrm{SnCl}_{3}\right)\left(\mathrm{PH}_{3}\right)_{2}\right]$ reaction. This observation might explain why no Pt-ClSnClF ${ }_{2}$ complex has been detected by NMR spectroscopy.
The mechanism of $\mathrm{Pt} / \mathrm{Sn}$ catalyzed propene hydroformylation ${ }^{29}$ and asymmetric styrene hydroformylation ${ }^{30}$ was investigated by us previously, employing DFT methods. The regioselectivity and the enantioselectivity were found to be determined in the olefin migratory insertion step in both cases. The estimated regioselectivitiy for the Pt-bis(monophosphine) system, based upon the computed relative rates of the individual reaction channels $(83 \%)$, revealed an excellent agreement with the experimental ones reported by Schwager and Knifton $(85 \%){ }^{18}$ For the chiral system, which was intended to model the Pt-chiraphos system employed by Consiglio and co-workers, ${ }^{31}$ an enantiomeric excess of $47 \%$ was computed agreeing reasonably with the experimentally determined value of $45 \%$. Our results suggested that the enantioselectivity is determined by the chiral backbone of the Pt-diphosphine moiety, rather than the chiral arrangement of the phenyl groups attached to the phosphorus atoms.

The QTAIM analysis revealed ring critical point in all Pt-olefin complexes with more pronounced distortion in the electron density distribution for complexes where the $\mathrm{SnCl}_{3}$ ligand accommodates the equatorial position (Fig. 4.). The energetically more preferred transition states for the asymmetric model possess $\mathrm{SnCl}_{3}$ in equatorial position as well with increased Pt-C distances. Moreover, no bond path can be observed between platinum and the internal olefinic carbon atom whereas Pt-C interactions are notably stronger for the higher energy transition states, where $\mathrm{SnCl}_{3}$ is in axial position (Fig. 6).

The position of the $\mathrm{SnCl}_{3}$ ligand is profound for the barrier of the aldehyde reductive elimination step. The trans arrangement with respect to the acyl group results in a more even electron density distribution (Fig. 7). The preferred pathway for the oxidative addition of $\mathrm{H}_{2}$ and the reductive elimination of the aldehydes is found to be the one when the arrangement of the hydrogen atoms is perpendicular to the $\mathrm{Pt}-\mathrm{C}_{\text {acyl }}$ bond (Fig 8). The dominant route for the aldehyde elimination involves the diphosphane ligand with axial-equatorial arrangement and the equatorial $\mathrm{SnCl}_{3}$ trans to the hydride ligand migrating to the acyl carbon.

The role of trichlorostannate was the subject of various studies even in the early 60s. Based on IR studies, measuring the Pt-H stretching frequency, Chatt and Shaw characterized a number of complexes of the trans- $\left[\mathrm{PtH}(\mathrm{X})\left(\mathrm{PEt}_{3}\right)_{2}\right]$ type and found that $\mathrm{SnCl}_{3}$ has a moderately strong trans-influence. ${ }^{33}$ The decrease of the force constant of the $\mathrm{Pt}-\mathrm{H}$ bond can straightforwardly be interpreted by means of NBO calculations. Fig. 9 depicts the donor-acceptor interaction characteristic for trans-[PtH(X) $\left.\left(\mathrm{P}_{2}\right)\right]$ complexes taking place between the lone pair of tin and the antibonding $\sigma_{\mathrm{Pt}-\mathrm{H}}^{*} \mathrm{NBO}$. The $\mathrm{n}_{\mathrm{Sn}} \rightarrow \sigma_{\mathrm{Pt}-\mathrm{H}}^{*}$ interaction accounts for the trans influence and it can be associated with a high stabilization energy. The interaction energy is the highest for ligand $\mathrm{SnF}_{2} \mathrm{Cl}$ $(1306.1 \mathrm{kcal} / \mathrm{mol})$ followed by $\mathrm{SnCl}_{3}(673.6 \mathrm{kcal} / \mathrm{mol})$ and it is much lower for the complex containing the chloro ligand $(90.2$ $\mathrm{kcal} / \mathrm{mol})$. This tendency is in accord with the structural (Pt-H distance) and IR (n(Pt-H)) descriptors as well as with the decrease of the Pt-H Wiberg bond index in the order of $\mathrm{SnF}_{2} \mathrm{Cl} \rightarrow \mathrm{SnCl}_{3} \rightarrow \mathrm{Cl}$ (see Table 1). The stronger the s-donor ability, the higher the electron density which is transferred from the lone pair of tin towards the $\mathrm{H}$ and $\mathrm{Pt}$ atoms which is in line with their more negative partial charge. The more pronounced hydride character in complex trans- $\left[\mathrm{PtH}\left(\mathrm{SnF}_{2} \mathrm{Cl}\right)\left(\mathrm{PH}_{3}\right)_{2}\right]$ might provide an explanation for the change of reactivity and selectivity for the tin(II) fluoride containing systems. 